\title{
JUST LOOK BEHIND THE DATA! CZECH AND HUNGARIAN OUTWARD FOREIGN DIRECT INVESTMENT AND MULTINATIONALS
}

\author{
Magdolna SASS - Jana VLČKOVÁ \\ (Received: 28 May 2019; revision received: 14 October 2019; \\ accepted: 30 October 2019)
}

\begin{abstract}
There has been an increase in outward foreign direct investment (FDI) and in the number of locallyowned or controlled multinationals in the Czech Republic and Hungary. However, data problems hinder to determine accurately the underlying trends and the main factors behind the changes. Data on outward FDI contain investment realised by all locally operational firms, regardless of their ownership. We rely on newly available balance of payments manual 6 (BPM) data and on company case studies. We show that outward investment by Czech firms must be much higher than what balance of payments data show. Hungary's case is the opposite. The leading Czech and Hungarian foreign investor firms can be categorised as "virtual indirect" foreign investors: they are in majority foreign ownership, but under domestic control. The reason for this special type of firms dominating in outward foreign direct investments can be found in the privatisation technique applied in these countries during the transition process.
\end{abstract}

Keywords: multinational companies, outward investment, indirect outward FDI, Czech Republic, Hungary, ultimate controlling owners

JEL classification indices: F21, F23, C8

Magdolna Sass, corresponding author. Researcher at the Centre for Economic and Regional Studies, Budapest, Hungary. E-mail: sass.magdolna@krtk.mta.hu

Jana Vlčková, Associate Professor at the Department of World Economy, University of Economics, Prague, Czech Republic. E-mail: jana.vlckova@vse.cz 


\section{INTRODUCTION}

The number of firms that have been successfully internationalised through foreign direct investment (FDI) from former transition economies of East Central and Eastern Europe (CEE) has been continuously increasing. There are many national-level studies, which try to explain why these multinationals have emerged, how they have internationalised, and how their internationalisation fits into the existing theories. The aim of our paper is to compare outward FDI and multinational companies, originating from two countries in the CEE region: the Czech Republic and Hungary. It relies on company case studies in comparatively analysing certain aspects of the Czech and Hungarian multinational firms. It shows that in both countries, the leading foreign investor firms can be categorised as "virtual indirect" foreign investors. This means that while they have foreign majority ownership, they are also under domestic control. On top of that, in the case of Czechia, they are even operating under the Czech control, but in a foreign location, while in the case of Hungary, they are under the Hungarian control in Hungary. The reason for this special characteristic of these firms can be found in the privatisation technique applied in these countries during the transition process, due to which certain companies could stay in domestic hands. However, the "construction" through which these firms have become the leading foreign investors, differs in the two countries. Our article first shows the evolution of outward FDI from the two countries and demonstrates that the real extent of outward FDI realised by domestic firms differs considerably from the one indicated by outward FDI statistics in the balance of payments (b.o.p.). We show that outward FDI by Czech-owned or -controlled firms may be much larger than what the b.o.p. data show, while in Hungary, the case may be the opposite. On the other hand, through company case studies we show the type of the companies that invested abroad and the mechanisms through which many of them can be considered locally controlled companies in spite of their foreign majority ownership.

The article is organised as follows. Section 1 presents the review of the related literature. In Section 2, we present the methodology applied and justify it with the presentation of data problems. We show how outward FDI from the two analysed countries evolved over time in Section 3. Section 4 presents an overview of the main outward investors and company case studies, followed by the discussion. The last one, Section 5 concludes. 


\section{REVIEW OF THE LITERATURE}

Does it really matter from where FDI originates? There are a few empirical studies which show that country of origin matters. For example, Wang et al. (2009) showed that in terms of motivations, there are significant differences between non-Chinese Western companies or Hong Kong, Macau and Taiwan firms investing in China. Ford et al. (2008) showed differences between the impacts on the US economy by multinationals of different origins. Thus, we can state that the internationalisation process and strategies of multinational firms is to some extent related to their country of origin. Furthermore, the importance of "own" multinationals can be underlined by the fact that these multinationals may have significant impact upon their home economies in various areas, such as in foreign trade, b.o.p. (e.g. through repatriation of profits), technology (technology transfer from the country of origin, or reverse technology transfer to it).

The number of post-transition multinationals, originating from the European post-transition economies, has been growing since the beginning of transition. These new firms were analysed by numerous studies which exhibit and emphasize certain special characteristics of them. Svetličič (2004) pointed out that the new multinationals from the (former) transition economies were different from both developed country multinationals on the one hand and emerging multinational companies on the other hand in many areas. These differences include their development, ownership shares in subsidiaries, ownership and type of investors, types of activities, geographical orientation, motivations, domestic push factors, external pull factors, and competitive advantages and strategy. Also, Stoian (2013) pointed out the differences between post-communist and emerging multinationals. Jindra et al. (2015) showed the changes in the location of outward FDI from the CEE after their accession to the EU, but underlined that the main motivations of the CEE multinationals remained market-seeking, with some increased importance of efficiency-seeking, and still negligible knowledge-seeking.

The importance of regional FDI flows into the CEE and within that, strong flows between certain country pairs (usually with common history, or even with a common country previously, such as between Czechia and Slovakia or between the countries that previously made up the former Yugoslavia) was emphasized by Radlo - Sass (2012). Similarity and geographical closeness acted as important factors in shaping outward FDI from the CEE countries. Besides the importance of common history, politics and policy, other studies underline the importance of institutions in shaping outward FDI in the CEE region, such as Stoian (2013). Gorynia et al. (2015) reinforced the finding showing that the Visegrad countries often located their major outward investment in other CEE economies with simi- 
lar institutional environments. Further factors include various push factors, such as the home country's level of economic development, the size of the home market, and the rate of economic growth as well as various technological variables, which is demonstrated by Andreff - Andreff (2017), who based their analysis on macro-level FDI data from 26 transition economies. The latter authors also make a link between inward and outward FDI. This link and the economic growth of these countries contributed to the increase in the number of their "own" multinationals. This is supported by the fact that based on the investment development path (IDP) theory, the emergence of local multinationals can be evaluated as a "natural" process. IDP was found to be valid for the transition economies, including the Visegrad countries, by many authors, for example Andreff (2003) or Boudier-Benseeba (2008).

Furthermore, there are numerous analyses at the country level. For the two countries analysed in this article, Sass et al. (2012) examined the leading Hungarian-owned or -controlled multinational companies. These companies show the high concentration of Hungarian outward FDI in terms of the number of investing companies. In other words, only a few firms are responsible for the overwhelming majority of outward FDI. According to their estimation, in 2010, three firms, MOL, OTP, and TriGránit were the leading Hungarian outward investors, who represented at least half of the total outward FDI stock. They emphasized that these three companies have majority foreign ownership, but not in foreign control. Motivated by this speciality, Sass et al. (2012) introduced the notion of "virtual indirect" investors for the leading Hungarian multinationals, in the case of which foreign majority ownership does not correspond to foreign control. Zemplinerova (2012) showed that in the case of the Czech Republic a similarly high concentration of outward FDI is evident. The most important foreign investing firm is CEZ (energy sector) and there are many indirect investors, who realise FDI in third countries through their Czech subsidiaries (e.g. the German Volkswagen).

The distinction between direct and indirect outward FDI was examined by few studies years ago: see UNCTAD (1998), Bellak (1998), Kalotay (2012), etc. The importance of this distinction is underlined by the fact that both direct and indirect FDI are included in the outward FDI statistics of a given country. Indirect FDI is an investment abroad undertaken by an affiliate of a foreign multinational company that has been established in a different host country from that of the host country of the new investment. Thus, in our case, foreign investment projects, undertaken both by indigenous, locally owned or controlled CEE multinationals and by local subsidiaries of foreign (non-CEE) multinationals, are included in the data. There is no separate statistical data available about direct and indirect outward FDI, though some estimation exists. For example, based on the studies prepared within the Emerging Market Global Players (EMGP) project con- 
cerning overall outward FDI, in the case of Slovenia (Jaklič - Svetličič 2009) and Poland (Kaliszuk - Wancio 2013), it is mainly indigenous firms that venture abroad with direct investments. In the case of Hungary (Sass - Kovács 2013), on the other hand, it is a handful of mainly foreign majority-owned, but at the same time Hungarian-controlled firms, which are responsible for the overwhelming majority of outward FDI. These "virtual indirect" investors, in the case of which foreign majority ownership does not correspond to foreign control, are much closer in their characteristics to direct than to indirect investors (Sass et al. 2012). Similarly, Rugraff (2010) showed the importance of indigenous companies in the case of Polish and Slovenian outward FDI, while in the case of Hungary and the Czech Republic he found that foreign majority-owned multinationals dominate. However, the availability of a longer history of outward investments by 2019 and new data allow us to analyse and compare Czech and Hungarian multinationals in more detail here. This is the main gap in the literature that our article addresses.

\section{METHODOLOGY}

As we could see in the review of the literature, data on outward FDI presented in the b.o.p. are misleading, as it "adds up" the amount of the direct investments abroad realised by locally-owned or controlled firms and those of local subsidiaries of foreign multinationals. For example, in Hungary, the local subsidiary of the German-owned Deutsche Telekom, M-Telecom is an important foreign investor, owning subsidiaries in Bulgaria, Macedonia, Montenegro and Romania. Another such example is the Korean Samsung, whereby the Hungarian subsidiary is the parent company of a Slovakian and a Czech subsidiary and of one Romanian branch (Sass 2016). Similarly, in the Czech Republic, the German Volkswagenowned Škoda Auto has established a subsidiary in India (Zemplinerova 2012), and besides India, it has subsidiaries in Slovakia and Russia. The Czech pharma firm, Zentiva was acquired in 2008 by the French Sanofi, has numerous subsidiaries in the region, and after the acquisition, Zentiva acquired the Swiss company Helvepharm. ${ }^{1}$ There are many other Czech companies with foreign owners who have subsidiaries abroad including Unipetrol (owned by the Polish PKN Orlen, energy), Iveco (Italian, buses) or Foxconn (Taiwan, electronics).

We use a newly available dataset on FDI stocks, broken down according to the nationality of the ultimate owner company. ${ }^{2}$ The ultimate controlling owner is a

https://www.zentiva.com/who-we-are/our-history

The data can be found on the OECD website: https://stats.oecd.org/Index.aspx? QueryId=64220: FDI positions by partner country BMD4: Inward FDI by immediate and by ultimate investing country. 
firm or a person, who owns or controls the FDI in question. In tracing the "real origin" of FDI in a host country, a new opportunity is provided by these data, which should be compiled by the national banks according to the latest balance of payments manual (BPM6) and the new benchmark definition of FDI (BMD4) (IMF 2009; OECD 2015). The new methodology complies with the realities of FDI, where the ultimate controlling investor of a project may differ from the direct investor, and thus, also their nationalities may differ. Multinationals increasingly use their foreign subsidiaries for channelling FDI to third (or fourth, fifth and so on) countries, for various reasons (Kalotay 2012), among which tax optimisation through using tax havens (Bojnec - Fertö 2018) or tax-friendly developed countries (Andreff 2015) clearly stand out. (Further reasons include organisational ones or, higher familiarity of subsidiary staff with the new location of FDI in a third country.) Thus, in principle, at present, two inward FDI datasets are available for each country: one based on the nationality of the immediate investor and another one based on the nationality of the ultimate investor.

Understandably, the task of tracing the ultimate investor multinational company is in certain cases problematic and requires substantial knowledge and resources, even if there are detailed guidelines published on identifying them (OECD 2015). That may be the reason why up until now only a few national banks published two datasets. Because these new data are available for inward FDI only, we use mirror data for the Czech Republic and Hungary from those countries, which already published these data. We apply simple statistical analysis on these data. However, only a few of countries published these data. Therefore, the main limitation of our methodology is that it is only a subset of host countries that present data on inward FDI from the Czech Republic or Hungary. We also show later that these countries may not even be the most important hosts to outward FDI from the analysed countries. However, in spite of this limitation, we think, an interesting insight can be gained through our analysis into one specific aspect of outward FDI from these countries.

Furthermore, due to the high concentration of outward FDI in terms of investing firms (as it was mentioned, in each country, only a few companies are responsible for the bulk of outward FDI), we selected a few firms from each analysed country, in order to illustrate the different categories of foreign investors. Detailed company case studies show the internationalisation path of firms through FDI. The company case studies concentrate on the following questions:

- What is the ownership structure of the company? Who is the real owner, what is its nationality?

- How has the internationalisation of the company evolved over time? What was their main motivation in FDI? 


\section{DEVELOPMENTS IN OUTWARD FDI FROM THE CZECH REPUBLIC AND HUNGARY}

The most important data sources for FDI are the b.o.p. published by the respective national banks. They are compiled according to the internationally agreed guidelines, and thus, they are directly comparable with each other. According to these data, there has been a considerable increase - with some fluctuations - in the outward FDI flows of both countries after 2000 (Figure 1).

In spite of the considerable increase in outward FDI flows, the two analysed countries are still minor outward investors in international comparison (Figure 2). Their outward stock is dwarfed by the inward stock of FDI, though compared to other countries of the region (Slovakia, Poland, two Baltic countries), their outward FDI stock is substantial.

It is important to note that the b.o.p. figures are based on the residency principle: they record, among others, FDI, which are carried out by local residents in another country in the case of outward FDI. Thus, when local affiliates of foreign multinational companies invest abroad, this is recorded as outward FDI of the country in question. (Similarly, if foreign affiliates or subsidiaries of local multinationals invest abroad, it is not counted as outward FDI by local multinational

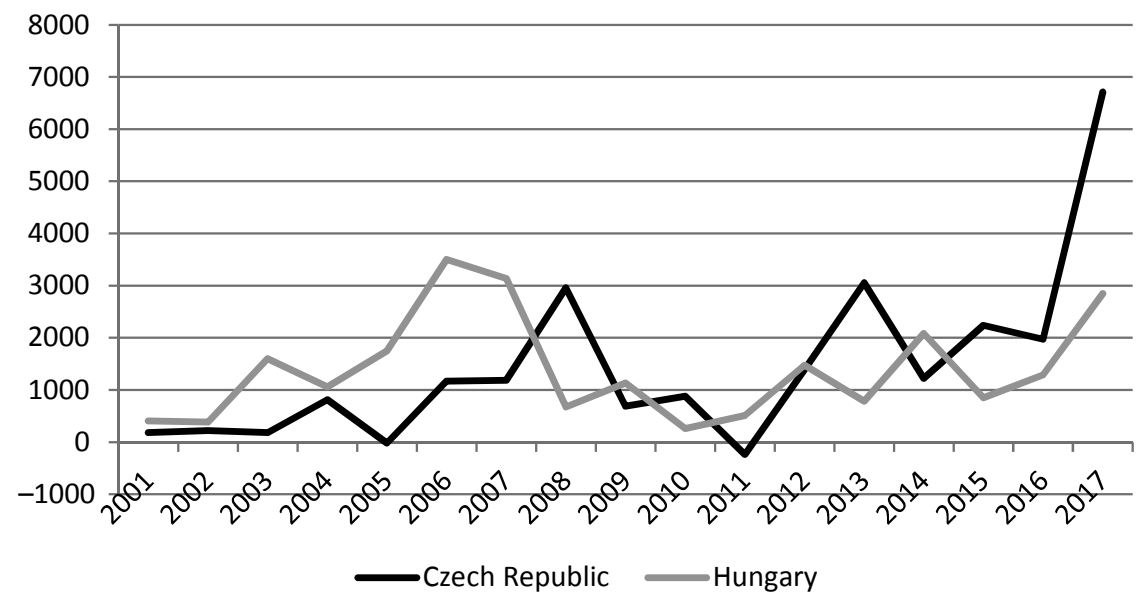

Figure 1. Outward foreign direct investment flows from the Czech Republic and Hungary, 2001-2017, million EUR

Source: www.cnb.cz and www.mnb.hu

Note: We started the analysis in 2001, because of data availability and the fact that outward FDI flows became significant from that year on (except for relatively substantial outflows from Hungary in 1997 and 2000, due to one-off, big transactions, see e.g. Sass et al. 2012). 


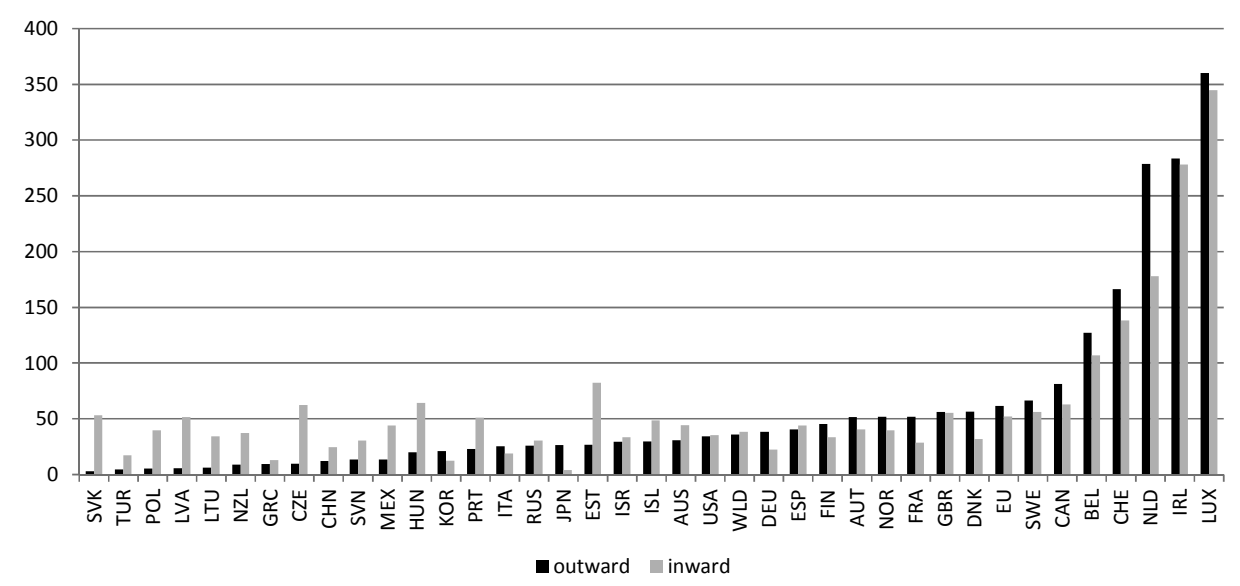

Figure 2. FDI stock as a \% of GDP, 2017

Source: OECD (https://data.oecd.org/fdi/fdi-stocks.htm)

firms.) Thus, on the basis of the data on outward FDI presented in the balance of payments, it is not possible to decide how much was invested abroad by the locally owned or controlled companies and how high can be the foreign assets of local enterprises.

In this respect, there are new developments. According to the new b.o.p. Manual, national banks should record the inward FDI stock according to the nationality of the ultimate investor. Thus, if we have a look at, for example, the data presented by the German Bundesbank on Czech and Hungarian FDI in Germany, based on the nationality of the ultimate owner, we get a clearer picture about "real" Czech and Hungarian outward FDI in Germany. These data must contain the FDI stock invested in Germany by firms, for which the ultimate owner (sometimes at the end of a long ownership chain) is either Czech or Hungarian. Here we compare two datasets for the two analysed countries: one, presented by the respective national bank on outward FDI stock in a certain country, and another one, published by the national bank of the country in question, on inward stock coming ultimately (i.e. owned or controlled ultimately) from the Czech Republic or Hungary. These mirror data give valuable insights into how the Czech or Hungarian multinationals are present in the given country and the comparison of the two datasets allows us to draw further conclusions regarding certain characteristics of the Czech and Hungarian outward FDI.

In certain cases, data are noted by the partner country as confidential. In these cases, there are usually one or two companies or private persons investing substantial amounts, and thus, their identities could be revealed by presenting the 


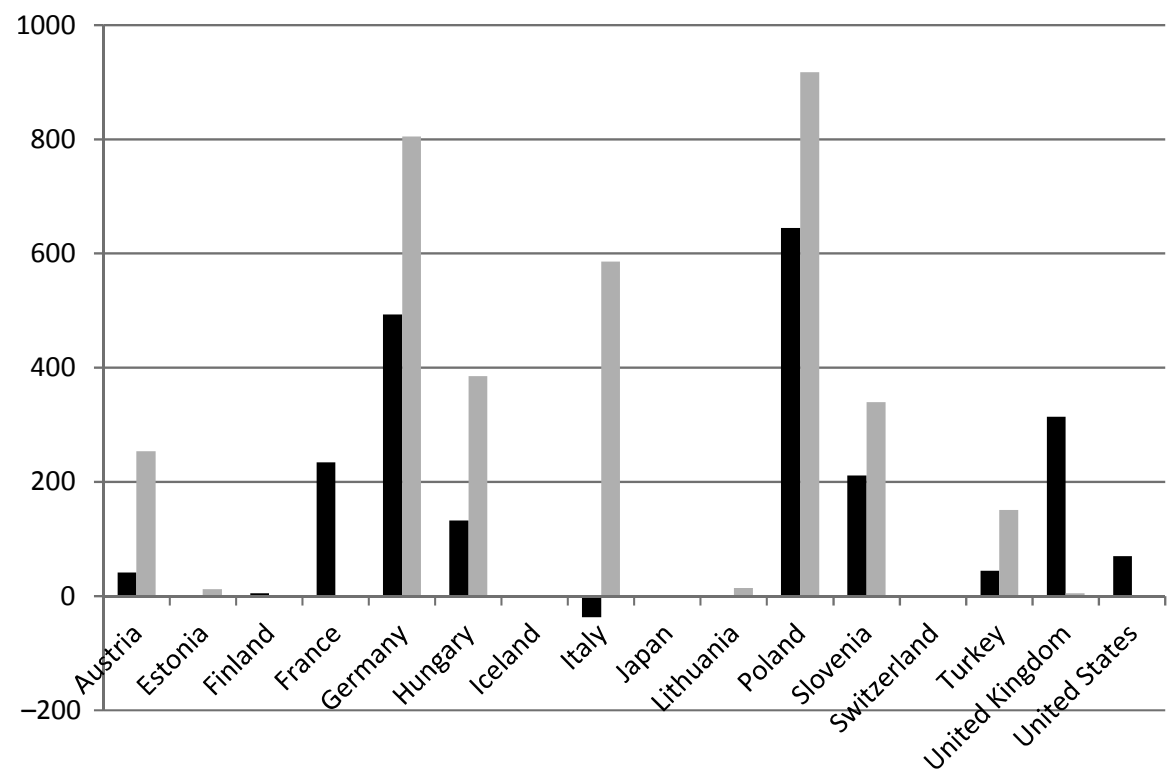

- Czech Republic own $\quad$ Czech Republic mirror

Figure 3. Outward foreign direct investments from the Czech Republic by partner countries, 2016, million USD

Note: Those countries which publish inward FDI data by ultimate beneficiary owners.

Source: Czech National Bank and OECD.

data. For the Czech Republic: Finland, France, Japan, Switzerland and United States indicate confidential or negligible sums of inward FDI coming from the country in question. In the case of Hungary, it is France, Japan, Lithuania, Switzerland and Slovenia, which do not present the data due to confidentiality or negligibility. In spite of these missing data, the available data reveal an interesting phenomenon when we compare them for the Czech Republic and Hungary (Figures 3 and 4).

In many countries, the stock of Czech FDI according to the final owners' nationality (i.e. ultimately owned or controlled by Czech firms) is higher than according to the data of the Czech National Bank, which records outward FDI originating on the "Czech soil" (the direct owner of the outward FDI is a resident in the Czech Republic) (Figure 3). Thus, the stock of the "really" Czech-owned FDI is considerably higher in Austria, Germany, Hungary, Italy, Poland, Slovenia and Turkey. Based on these data we can assume that the stock of outward FDI from the Czech Republic can be considerably higher than the one presented in the b.o.p.s. 


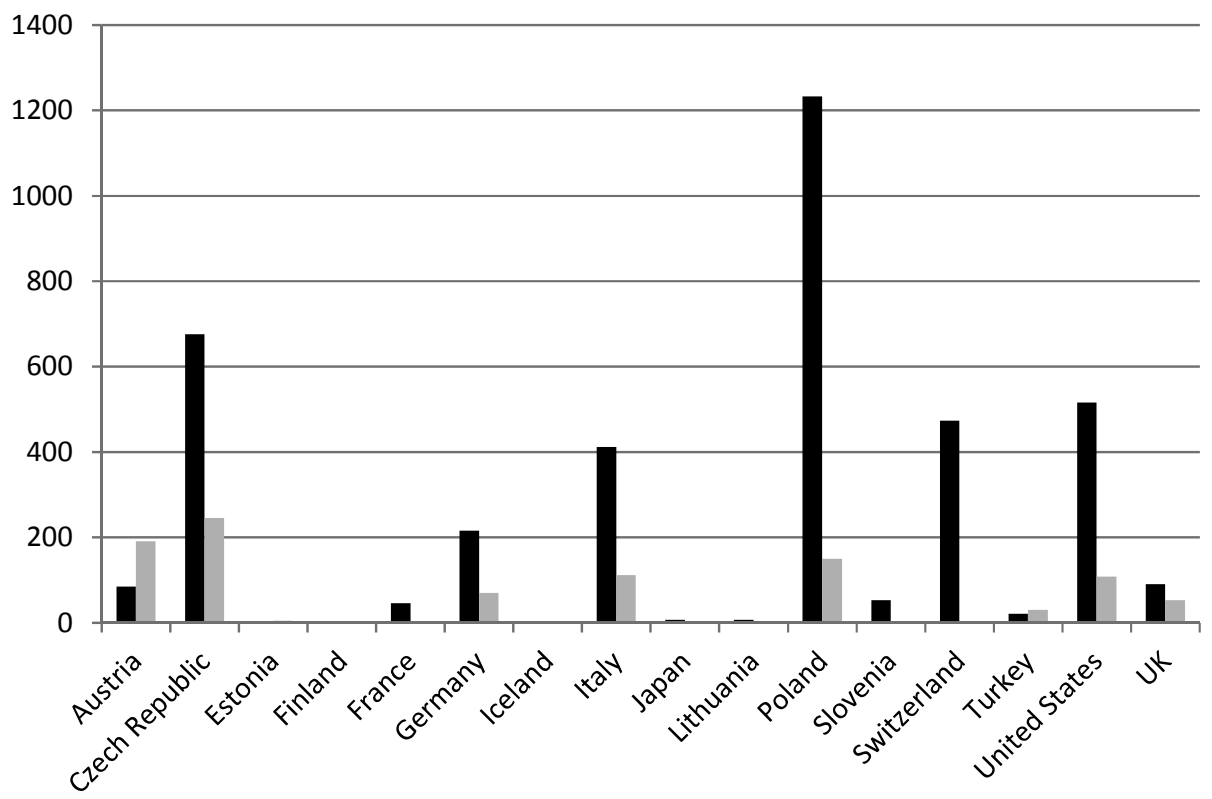

- Hungary own Hungary mirror

Figure 4. Outward foreign direct investments from Hungary by partner countries, 2016, million USD

Note: Only those countries which publish inward FDI data by ultimate beneficiary owners.

Source: Magyar Nemzeti Bank and OECD.

In the case of Hungary, we find just the opposite (Figure 4). Usually, the data recorded by the Hungarian central bank are much higher than those presented by the respective partner national banks. The difference is in such direction and considerable in the case of the Czech Republic, Germany, Italy, Poland and United States. This indicates that outward FDI from Hungary in these countries is not ultimately owned or controlled by the Hungarian firms or private persons, and in these cases the Hungarian subsidiaries are "used" by foreign-owned multinational companies to realise (and mediate) their FDI into the third countries. Thus, we can assume that the outward FDI stock of Hungary, as reported by the Hungarian side is considerably higher than the outward FDI stock realised by the Hungarianowned or controlled companies. However, it is important to note that the countries which present the data are not the main directions of outward FDI from Hungary, neither according to the data of the Hungarian national bank (according to which the leading host countries are Croatia, Israel, Cyprus, Slovakia and Belgium, altogether $50 \%$ of the total stock), nor according to other sources that are based on 
company level data (i.e. the Central European countries) (Sass - Kovács 2015). Thus, Figure 4 presents data only on a part of the Hungarian outward FDI. As we already mentioned, this is an important limitation of our analysis.

Our assumptions are reinforced by another data, available according to $6^{\text {th }}$ Edition of the Balance of Payments Manual (BPM6) methodology. The absolute value of roundtripping is a good indicator for showing the inclination of local entrepreneurs to keep their capital abroad and bring it back to their own country as foreign capital. This is much higher in the Czech Republic than in Hungary. In 2016, in the case of Hungary, roundtripping (where the ultimate owner of a direct investment in Hungary is a Hungarian) represented only $0.43 \%$ of the total stock of inward FDI (326 million EUR). On the other hand, in the case of the Czech Republic that share is $8.5 \%$ (with a value of almost 10 billion EUR). ${ }^{3}$ Thus, we can see that the inclination of the Czech entrepreneurs is much higher relative to their Hungarian counterparts, to keep their money or capital abroad. This can be perceived as a factor, which supports our assumption about the Czech multinationals, who have a much larger stock of direct investment abroad than what is reflected by the statistics published by the Czech National Bank. On the other hand, outward FDI realised by the Hungarian firms is smaller than we can assume based on the outward FDI data of the Hungarian national bank.

Due to the complexity of the problem and to double-check the above assumptions, we prepared detailed company case studies of locally controlled foreign investor firms from the two countries. We compiled our company sample so that it contained one of the leading investor firms (based on results of the literature), and to include other investors, which correspond to our assumption, especially in the case of the Czech Republic: ultimately Czech controlled or owned multinational firms.

\section{COMPANY CASE STUDIES}

Going down to the company level helps us to differentiate between locally-owned or -controlled and foreign-owned investor companies in the two countries. First, we have a look at the foreign investing firms in these countries, and then we present three company cases, which help us illustrate their most important characteristics, especially in terms of their ownership structure (nationality of ultimate and direct owner) and their internationalisation processes.

In international comparison, however, these shares are not outstandingly high or low: for example based on OECD data, in 2016, in the case of Germany and Italy it was 8.5\%; Estonia: $7.4 \%$, France: $6.9 \%$ and at the other extreme, Canada: $1 \%$, Austria: $1.5 \%$ and the US: $2 \%$. 


\subsection{Czech multinationals}

As we already mentioned, one group of companies investing abroad from the Czech Republic includes subsidiaries of foreign multinationals, such as Škoda Auto, Zentiva, Iveco, Unipetrol or Foxconn. Another group is that of locallyowned or -controlled firms. This latter includes traditional small- and mediumsized firms (SMEs) as well as emerging technological multinationals. Some of them even belong to the so called "born globals" (Vlčková 2019).

- Kiwi was established in 2011 under the name Skypicker and it is basically a flight search engine. Kiwi.com was named the fastest-growing technology company in Central Europe by Deloitte's Technology Fast 50 Central Europe and currently has subsidiaries in Spain and the Netherlands (Deloitte 2018).

- Socialbakers is a global AI-powered social media marketing company offering marketing software for social media. It has subsidiaries in the United States, Germany, United Kingdom and Croatia.

- Avast Software s.r.o. is a Czech multinational cybersecurity software company which has more than 435 million users and the largest market share among anti-malware application vendors worldwide, as of January 2018. Avast was founded by Pavel Baudiš and Eduard Kučera in 1988 as a cooperative and had its IPO in May 2018. The company has approximately 1,700 employees across its 25 offices worldwide including the United States, Japan, Germany, and Great Britain ${ }^{4}$. However, the ultimate owner of Avast PLC is based in the United Kingdom, though its Czech founders still own over $40 \%$ of the firm. Avast is very important from the point of view of our analysis, because it shows a common example of firms controlled by Czech citizens with a seat abroad, supporting our analysis carried out at the macro level.

The b.o.p. outward FDI data does not include investment made by these firms, the headquarters of which is located abroad. Many domestic firms (especially financial groups) use other countries as their tax residence in order to pay lower tax and/or due to different and more beneficial regulations than the Czech ones. According to latest data, almost 13 thousand Czech firms are controlled by owners from tax havens with total assets reaching 327 billion CZK ${ }^{5}$ (Ihned 2019). Undoubtedly, these also include firms owned by Czech residents (see the case of PPF below). However, over the last five years the number of Czech firms con-

4 https://investors.avast.com/our-story/at-a-glance/

5 More than 12 billion EUR. 
trolled from abroad has been decreasing. This is related to changes in the business environment, breaking the banking secrecy (Panama and Paradise Papers) and the introduction of the registry of end-owners. At present, the Netherlands still dominates the list with over 3600 Czech firms controlled from there (28\%), however, their share stood at 38\% in 2010 (Ihned 2019). This is related to the fact that Czechia (and Slovakia as well) signed in 1992 an "Agreement on encouragement and reciprocal protection of investments between Czech and Slovak Federal Republic and the Kingdom of Netherlands". This agreement stipulates that the Dutch owner of Czech firms could sue Czechia for devaluation of investment (for example, in the case of changes in taxation, etc.). However, there is a breakthrough case C-218/16 Achmea from 2018 between Slovakia and Netherlands, which states that the arbitration clause included in the bilateral investment between the two Member States is incompatible with the EU law ${ }^{6}$. Therefore, we can assume that the number of Czech firms controlled from EU member states will gradually decrease. The other favourite destinations are United States (23\%) and Cyprus (17\%), the share of these two countries are continuously increasing (although in the case of Cyprus it may be declining due to incompatibility with the EU law).

So, how can we estimate the extent of the Czech controlled outward FDI? Among the largest companies in Czechia (based on sales) there are only three Czech-owned companies: ČEZ, Agrofert and EPH. Other companies, such as Škoda Auto, Hyundai and Foxconn are foreign owned. All these three large Czech companies are important foreign investors ( $\breve{C E Z ~ i s ~ d e s c r i b e d ~ b e l o w ~ i n ~ d e t a i l) . ~}$ A look at the richest people in Czechia complements this statement. For example, the richest person Petr Kellner owns and runs the PPF Group, active mainly in financial services and located in the Netherlands. Among the top wealthy people in Czechia, the largest share is composed by businessmen in their 50s and $60 \mathrm{~s}$, who earned their fortune in the privatization period and now focus mainly on energy and/or finance/investment (Forbes 2018). Investment in media and/or entry into politics is also common. The share of self-made Czech billionaires is steadily rising, particularly in e-commerce, energy and finance. Among the top 10 richest people, seven have the seat of their companies/groups abroad. This includes PPF Group (finance; seat in Netherlands), KKCG (energy, investment; seat in Switzerland), CPI (real estate with a seat Luxemburg), Sev.en Commodities (energy, Lichtenstein), Penta Investments (investment, Cyprus), and Avast (software, UK). On the other hand, Czech-based firms include Agrofert (chemicals) or EPH (energy). If we compare this with Germany, all of the companies of the ten wealthiest Germans are headquartered in Germany. According to the 
Amadeus database, there are over 360 Czech firms, which are dominantly (with a share exceeding $50 \%$ ) owned by a foreign company, where the majority ownership of this foreign company belongs to Czech citizens. This includes, among others, firms belonging to the PPF Group.

\section{Company case studies}

In the following parts three case studies are described in detail. The PPF Group N.V. as a major financial group is seated in Netherlands, ČEZ Group is a Prague based energy conglomerate and LINET Group SE, a hospital beds manufacturer, is based in Netherlands.

Table 1. Selected indicators of the three companies, million EUR

\begin{tabular}{l|l|l|l|l|l|l|l|l|l}
\hline (Mil. EUR) & \multicolumn{3}{c|}{ PPF Group NV } & \multicolumn{3}{c|}{ ČEZ Group } & \multicolumn{3}{c}{ LINET Group SE } \\
\hline Year & 2015 & 2016 & 2017 & 2015 & 2016 & 2017 & 2015 & 2016 & 2017 \\
\hline Operating revenues & 5941 & 6506 & 6145 & 210 & 204 & 202 & 184 & 235 & 229 \\
\hline Total Assets & 21611 & 27041 & 38222 & 603 & 631 & 626 & 333 & 408 & 386 \\
\hline ROE (\%) & 19.1 & 14.8 & 15.8 & 7.8 & 5.4 & 7.4 & 4.0 & n.a. & 11.0 \\
\hline
\end{tabular}

Source: Own calculations based on the Amadeus database.

\section{PPF Group N.V.}

Správa Prvního privatizačniho fondu (Administration of the First Privatization Fund, PPF) was set up in 1991 by Petr Kellner and his partners; the first four privatisation funds were registered at the end of the year. PPF holding company was registered in the Netherlands, Amsterdam in 1994. In 2017, the assets managed by PPF Group N.V. reached EUR 38 billion and PPF had operations in 22 countries and employed 170,000 people. Petr Kellner is the founder and majority shareholder of PPF Group N.V. (share of voting rights: 98.92\%), two other shareholders include Ladislav Bartoníček and Jean-Pascal Duvieusart (both have 0.54\%).

PPF's major activity is financing (Table 2). Home Credit, where PPF has 90\% share, is a non-banking financial institution founded in 1997, which focuses on lending primarily to people with little or no credit history. Currently, it has almost thirty million clients around the world, including Czechia, Russian Federation, China and United States. Apart from that, PPF also owns Air Bank in Czechia. Telecommunications is another key PPF domain. It has majority stake in the Czech telecom firm O2 (whose subsidiary is the Slovak O2), and infrastructure company, CETIN. In summer of 2018, PPF expanded its telecommunications portfolio by buying 
Table 2. Various business segments and companies owned by PPF

\begin{tabular}{|c|c|c|c|c|}
\hline Segment & $\begin{array}{l}\text { Business name/ } \\
\text { brand }\end{array}$ & $\begin{array}{l}\text { Approximate } \\
\text { share of PPF } \\
\text { Group N.V. }\end{array}$ & Operations & Geographicfocus \\
\hline \multirow{5}{*}{$\begin{array}{l}\text { Banking and } \\
\text { consumer } \\
\text { finance }\end{array}$} & Home Credit & $88.62 \%$ & $\begin{array}{l}\text { Lending to private individual } \\
\text { customers, deposit- taking }\end{array}$ & $\begin{array}{l}\text { Czech Republic, } \\
\text { Slovakia, Russia, } \\
\text { Asia, USA } \\
\end{array}$ \\
\hline & Air Bank & $88.62 \%$ & $\begin{array}{l}\text { Deposits, loans and other } \\
\text { transactions and balances with } \\
\text { retail customers }\end{array}$ & Czech Republic \\
\hline & $\begin{array}{l}\text { subsidiaries of } \\
\text { PPF banka and Air } \\
\text { Bank }\end{array}$ & $88.62 \%$ & $\begin{array}{l}\text { Lending to private individual } \\
\text { customers }\end{array}$ & $\begin{array}{l}\text { Czech Republic, } \\
\text { Slovakia, Russia }\end{array}$ \\
\hline & PPF banka & $92.96 \%$ & $\begin{array}{l}\text { Loans, deposits and other } \\
\text { transactions and balances with } \\
\text { corporate customers, trading } \\
\text { activities }\end{array}$ & $\begin{array}{l}\text { Czech Republic } \\
\text { ClearBank } \\
\text { (associate) }\end{array}$ \\
\hline & Clear Bank & $36.36 \%$ & $\begin{array}{l}\text { Clearing and settlement } \\
\text { services }\end{array}$ & United Kingdom \\
\hline \multirow{2}{*}{$\begin{array}{l}\text { Telecommu- } \\
\text { nications }\end{array}$} & $\mathrm{O} 2$ & $83.40 \%$ & $\begin{array}{l}\text { Telecommunication operator } \\
\text { providing a range of voice and } \\
\text { data services }(\mathrm{CZ}), \text { mobile } \\
\text { operator }(\mathrm{SK}) \\
\end{array}$ & $\begin{array}{l}\text { Czech Republic, } \\
\text { Slovakia }\end{array}$ \\
\hline & CETIN & $100 \%$ & $\begin{array}{l}\text { Administration and operation } \\
\text { of data and communication } \\
\text { network }\end{array}$ & Czech Republic \\
\hline Real estate & $\begin{array}{l}\text { PPF Real Estate } \\
\text { Holding }\end{array}$ & $100 \%$ & $\begin{array}{l}\text { Developing, investing and } \\
\text { professional consulting in the } \\
\text { property sector }\end{array}$ & $\begin{array}{l}\text { Central and } \\
\text { Western Europe, } \\
\text { Russia, Ukraine } \\
\end{array}$ \\
\hline Insurance & PPF Insurance & $100 \%$ & $\begin{array}{l}\text { Provision of life insurance } \\
\text { products }\end{array}$ & Russia \\
\hline \multirow{6}{*}{ Other } & Sotio & $92 \%$ & $\begin{array}{l}\text { Development of new medical } \\
\text { therapies, focusing on the } \\
\text { treatment of cancer and } \\
\text { autoimmune diseases }\end{array}$ & $\begin{array}{l}\text { Czech Republic, } \\
\text { USA, China }\end{array}$ \\
\hline & RAV Holding & $100 \%$ & $\begin{array}{l}\text { Grain and livestock produc- } \\
\text { tion, storage and trade }\end{array}$ & Russia \\
\hline & O2 Arena & $100 \%$ & $\begin{array}{l}\text { Operation of multipurpose } \\
\text { hall hosting mainly sports } \\
\text { and cultural events }\end{array}$ & Czech Republic \\
\hline & \begin{tabular}{|l|} 
The Culture Trip \\
\end{tabular} & $43.69 \%$ & $\begin{array}{l}\text { Online publishing and book } \\
\text { selling }\end{array}$ & worldwide \\
\hline & LEAG (JV) & $50 \%$ & $\begin{array}{l}\text { Extraction, processing, refin- } \\
\text { ing and sale of lignite, genera- } \\
\text { tion of electricity and heat }\end{array}$ & Germany \\
\hline & \begin{tabular}{|l|}
$\begin{array}{l}\text { Mall/Heureka } \\
\text { (associate) }\end{array}$ \\
\end{tabular} & $40 \%$ & $\begin{array}{l}\text { e-commerce and comparison } \\
\text { shopping platforms }\end{array}$ & $\begin{array}{l}\text { Central and } \\
\text { Eastern Europe }\end{array}$ \\
\hline
\end{tabular}

Source: PPF Group Annual Report 2017. 
Telenor's companies in the Central and South-eastern Europe (Ihned 2018a). At the end of 2017, PPF acquired Škoda Transportation, the Czech Republic's most important engineering company and major Central European manufacturer of rolling stock. PPF is also getting involved in biotechnology. Its company SOTIO is running eleven clinical trials for the treatment of cancer, based on DCVAC technology. In the summer of 2018, PPF finished the acquisition of the French company Cytune Pharma focusing on oncological treatment (Ihned 2018b). PPF also has real estate projects (e.g. O2 Arena) and shares in e-commerce companies: $40 \%$ of the shares in the second largest Czech e-shop, Mall.cz, and the price comparator Heureka. Apart from that, PPF also invests in its clearing bank project in the UK (ClearBank) and in Culture Trip, the international media technology project.

In 2018, apart from several acquisitions, PPF was also coping with the new regulations imposed on the entire consumer finance sector in China. The PPF Group became the first foreign entity to be licensed by the Chinese regulator to provide consumer finance services in 2010. Considering the group credit risk, $70 \%$ is household/individuals (consumer market) and in terms of geographic concentration, $45 \%$ is in China, 19\% in Czechia and 17\% in Russia (PPF 2018). Despite significant growth in other markets including Russia and Kazakhstan, the Chinese market is highly important. One of the ways to diversify risks is the focus more on online lending via mobile apps. At the beginning of 2019, there was a dispute between Czechia and China resulting from the formal warning of NUKIB (National Cyber and Security Agency) against the use of equipment and software produced by Chinese companies Huawei and ZTE. This could not only affect the PPF's operations in China, but also its telecommunications sector (Telenor and Cetin), since there were plans to develop 5G networks with Huawei (Lupa 2019).

\section{$\check{C} E Z$ Group}

ČEZ Group is an integrated energy conglomerate headquartered in Prague. ČEZ a.s. was established in 1992 as the shares of České Energetické závody were transferred to a new company. Part of the shares was privatised. Currently, the Czech state has nearly 70\% stake in the company's base capital, 19\% belongs to other legal entities and $10 \%$ to private individuals. In 2003, ČEZ was merged with the distribution companies. The core business of ČEZ Group is the generation, distribution, trade in and sales of electricity and heat, trade in and sales of natural gas, and coal extraction as well as providing comprehensive energy services. In Czechia, ČEZ produces more than three quarters of electricity. Apart from Czechia, ČEZ Group has operations in France, Poland, Romania, Bulgaria, Slovakia and Turkey, and employs more than 30,000 people worldwide. 
In the first decade of the new millennium, ČEZ closed many acquisitions and joint ventures particularly in South-East Europe in order to become the number one player in the Central and Southeastern Europe. This goal was achieved, although in recent years some of the acquisitions have been found to be unsuccessful. In January 2013, an Albanian regulator of CEZ Shpërndarje removed the license and its management was taken over by the designated administrator on the grounds that the company did not meet its electricity supply obligations. ČEZ completely lost control over its subsidiary and decided to defend itself by arbitration. In the end, however, ČEZ and Albania concluded a settlement agreement, which required the country to pay back an initial investment of about 2.75 billion crowns, in installments up to this year. In 2016, ČEZ Group officially filed a Request for Arbitration against the Republic of Bulgaria with the International Centre for Settlement of Investment Disputes (ICSID), by which it officially commenced international investment arbitration proceedings due to Bulgaria's failure to observe the investment protection provisions of the Energy Charter Treaty. ČEZ already sold coal power plant in Varna and it is currently selling its remaining Bulgarian assets (EnergyHub 2018). ČEZ also faces problems in Turkey, war conflict in Syria and economic crises affect their operations.

With the transformation of the energy sector, ČEZ is going through significant changes. New technologies, legislative changes, setting the EU targets and high volatility of wholesale electricity prices have a major impact. The net income has been declining steadily since 2009 . In 2017, there was an increase, but this was related to the sale of $7.5 \%$ stake in the Hungarian petrochemical company MOL, Hungarian Oil and Gas PLC MOL shares, in the first half of 2018 year on year income fell from CZK 16.7 billion to 7.7 billion CZK (CT24 2018).

ČEZ responds to industry changes. In 2014, ČEZ set up a venture capital fund, INVEN CAPITAL, to fund innovative clean-tech companies in Europe. ČEZ has invested in companies called Sonnen, Sunfire and tado ${ }^{\circ}$ and the ETF LP to support the development of innovative energy businesses, widen their business and integrate these areas into ČEZ's energy business. In 2017, ČEZ Group acquired Elevion, a leading German provider of comprehensive energy services. Further, it entered the Polish market by acquiring OEM Energy, acquired several wind parks and its development projects in Germany and France and began providing ESCO energy services in Slovakia. In 2018, C̆EZ acquired Polish company Metrolog sp. z o.o. and a $25 \%$ stake in ENESA (ČEZ 2018). The ČEZ Group companies are also investing in research and development, in 2017, its expenditure on R\&D exceeded one billion CZK (ČEZ 2018). Despite the fact that ČEZ faces problems in the South-Eastern parts of Europe, it faces other challenges: the transformation of ČEZ and completion of two nuclear power plants in Temelín and Dukovany. Both are politically very sensitive questions. 


\section{LINET Group SE}

LINET spol. s.r.o. is a major European manufacturer of hospital and nursing beds. The company was established in 1990 in Želevčice u Slaného (Central Bohemia region) by Mr. Frolík and currently produces over 100,000 hospital beds per year with annual sales of cca. 300 million EUR. Around $90 \%$ of this is exported to over one hundred countries worldwide, although the major export markets are Germany and the USA.

The major products include solutions designed for intensive care, products for regular in-bed treatment and special beds for old people's homes and long-term care facilities. LINET also provides other accessories, such as anti-pressure ulcer mattresses, mobile equipment, healthcare furniture, etc. In 2016, LINET acquired $80 \%$ of the Czech firm Borcad Medical, which focuses on the production of birthing beds and gynaecological chairs. LINET is highly innovative, cooperates closely with healthcare professionals and new products and accompanying services are being introduced every year. LINET s.r.o. owns over 70 patents (Czech, as well as European). The operating revenue has been growing rapidly, despite a small drop in 2016, and in the fiscal year ending in March of 2018, the company earned 252 million Euros (Table 1).

Since 2011 LINET s.r.o. has become part of the multinational holding LINET Group SE with registered offices in the Netherlands. The motivation for that was to gain investment protection as well as planned entry to foreign exchange and also the fact that the holding structure in the Netherlands does not tax dividends (Ekonom 2011). The owners of the newly established company are the Czech LINET Holding and the German WIBO Holding GmbH, which joined LINET in Želevčice near Slaný in the 1990s as co-owner. At present, half of the LINET Group is still Czech owned (33\% belong to Mr. Frolík's family) and the other half is owned by German citizens. According to press news, a part of LINET should be sold to foreign investment groups, the two major interested parties are CVC Capital - an American equity fund and Chinese Sino - CEE Fund (Ihned 2018c).

LINET has production in Czechia (Želevčice), where it employs around 900 people, and in German Wickede with over 500 employees. The LINET Group also has twelve other subsidiaries in France, USA, Belgium, Mexico, Brazil, Italy, Great Britain, Sweden, Netherlands, United Arab Emirates and Russia, serving as representative offices. 
Table 3. Companies, owned by Linet Group

\begin{tabular}{l|c|c}
\hline Company name & Country & Ownership (\%) \\
\hline LINET AMERICAS INC & US & 100.00 \\
\hline LINET DO BRAZIL LTDA & BR & 100.00 \\
\hline JИHET ЦEE & RU & 100.00 \\
\hline LINETspol. s r.o. & CZ & 100.00 \\
\hline WIBO SERVICES GMBH & DE & 100.00 \\
\hline wissner-bosserhoff Nederland B.V. & NL & 100.00 \\
\hline LINET IBERIA SL. & ES & 100.00 \\
\hline LINET UK LIMITED & GB & 100.00 \\
\hline Materská skola Linetka, s.r.o. & CZ & 100.00 \\
\hline WISSNER-BOSSERHOFF BELGIUM & BE & 100.00 \\
\hline WISSNER-BOSSERHOFF FRANCE & FR & 100.00 \\
\hline WISSNER-BOSSERHOFF GMBH & DE & 100.00 \\
\hline LINET FRANCE SAS & FR & 99.70 \\
\hline Borcad Medical, a.s. & CZ & n.a. \\
\hline LINET ITALIA S.R.L. & IT & 51.00 \\
\hline LINET DO BRASIL COMERCIO, IMPORTACAO E & BR & n.a. \\
EXPORTACAO DE PRODUTOS MEDICAL & & \\
\hline
\end{tabular}

Source: Amadeus database.

\subsection{Hungarian multinationals}

Hungary was considered to be for a long time one of the leading outward investor countries of the CEE region. This was partly due to indirect outward FDI, realised by the Hungarian subsidiaries of foreign multinationals, such as the German Deutsche Telekom, the Korean Samsung or the Taiwanese Foxconn, which used their Hungarian subsidiaries to realise FDI in the region or even in faraway countries ${ }^{7}$. Hungarian-controlled multinationals is also a mixed group, similarly, as in the case of Czechia. Certain Hungarian firms are among the top multinationals in the region according to their foreign assets (such as the petrol company, MOL or OTP Bank (Kalotay - Sass 2019)). Besides the large foreign investor companies (MOL, OTP and Richter Gedeon), we can also find medium to large locally-owned firms with more limited foreign assets, such as the elec-

7 There is no information about their motivations. For the Korean Samsung we assume that the main reason could be the vicinity and familiarity of the Hungarian management and units to the target countries (Czechia, Romania and Slovakia) (Sass 2016). In the case of Deutsche Telekom we can assume similar motivations, while for the Taiwanese company, which realised investment from Hungary to Brazil and Denmark, maybe a trade-off between different tax schedules and regulations can be the cause, i.e. tax optimisation. 
tronics service provider: Videoton, and another important supplier to mainly foreign-owned firms: Jászplasztik, operating in the plastics industry (Sass - Kovács 2015). There are also small to medium companies, usually in the high tech domain, which internationalise quickly and basically from their establishment, and thus can be characterised as "born globals", among them we can find numerous small- to medium-sized medical precision instruments producing, biotechnology or IT firms (Kozma - Sass 2019; Stocker 2019). For example, 3DHistech, which was established in 1997, operates in the medical devices sector, producing virtual microscopes. Among these companies, changes in the ownership structure, mainly due to acquisitions by developed country firms, is relatively frequent. For example, Graphisoft was a well-established Hungarian architectural software producer, with numerous foreign affiliates and representatives, acquired by the German Nemetschek AG, an important player worldwide in the same segment. ${ }^{8}$ Balabit, an IT firm, was acquired in 2018 by One Identity, the ID and access management unit of the U.S.-based Quest Software company. ${ }^{9}$ Solvo is a Szeged-based biotechnology firm, a global leader in the field of transporter protein research. It was acquired by the French Citoxlab Group in $2018 .{ }^{10}$ On the other hand, more similarly to the Czech Avast, NavNGo or now NNGO had a "mixed" ownership background, it was founded by two Israeli businessmen and several Hungarian technical professionals, but operates since its foundation in 2004, in Hungary. ${ }^{11}$

For Hungary, information on the top foreign investing Hungarian-owned or -controlled non-financial firms is available from the EMGP project. ${ }^{12}$ The latest list of top foreign investors is available for 2013. 20 MNEs held more than US\$ 20 billion in foreign assets with the top-ranked firm, MOL Group accounting for almost US\$ 19 billion (OTP Bank, as a financial firm, is not included in the analysis). Due to the dominance of MOL, outward FDI by the Hungarian companies went primarily into oil and gas exploration and production (mining and quarrying) and pharmaceuticals. The contribution of pharmaceuticals primarily comes from the activities of the second firm in the ranking: Gedeon Richter. Other investment areas included electronics, construction, transportation and storage, manufacturing of medical precision instruments, building materials, plastics

8 https://bbj.hu/finance/nemetschek-acquires-54-of-graphisoft-shares-plans-public-offer-injanuary_20940

9 https://bbj.hu/business/hungarian-it-company-bought-for-an-estimated-usd-100-million_ 144225

$10 \mathrm{https} / / / \mathrm{bbj} . \mathrm{hu} /$ business/hungarys-solvo-biotechnology-sold-to-french-investor_146921

11 https://www.bloomberg.com/research/stocks/private/snapshot.asp?privcapId=37222121

12 The website of the Emerging Market Global Players (EMGP) project is available at http://ccsi. columbia.edu/publications/emgp/ or https://emgp.org 
production, construction and other manufacturing and services industries. The subsidiaries were mainly located in neighbouring and geographically close countries: Romania, Slovakia, Poland, Ukraine, Bulgaria, the Czech Republic and Germany (Sass - Kovács 2015).

An important and specific feature of the Hungarian firms, which are important foreign investors, is their "virtual indirect" nature (Sass et al. 2012). "Virtual indirect" investor firms are majority foreign-owned but domestically controlled firms, where the majority foreign ownership does not go together with foreign control for various reasons. In the case of Hungary, we can distinguish two types of "virtual indirect" foreign investor firms. The first group belongs to the relatively large privatised companies in the stock exchange, which, due to this special way of privatisation, have a dispersed majority foreign ownership with no controlling owner. The absence of the controlling owner, in certain cases, is enhanced by the special regulations, for example as in the case of the Hungarian MOL, where no firm or individual can have more than $10 \%$ voting rights, even if it owns more than $10 \%$ of the shares (Sass et al. 2012). Further company cases include OTP Bank and Richter Gedeon. While these company cases seem to be ambiguous, their classification as "virtual indirect" investor is reinforced by the EMGP project pointing at local control (for example, the CEOs/directors are local citizens, the managerial board consists mainly or exclusively of local citizens, the language used in the firm is local and/or English, etc.) (Sass - Kovács 2015). We can distinguish a second group of "virtual indirect" investors, connected to round-tripping, when the domestic investor first sets up a foreign subsidiary, and then this foreign subsidiary invests in the domestic economy, and later invests in abroad. For example, the Hungarian Tri-Gránit is majority owned by a foreign company (based in Cyprus), which is in turn owned by a Hungarian private person. TriGránit is responsible for large greenfield investment projects in real estate and construction (Sass - Kovács 2013). Obviously, these outward FDI projects are in reality outward FDI by the Hungarian-controlled companies.

Detailed company case studies shed light on certain important characteristics, including the ownership, control and motivations, of these outward investors.

\section{Company case studies}

We have selected three outward investing Hungarian companies as well. The pharmaceutical company, Richter Gedeon is believed to be the third most important foreign investor firm behind MOL and OTP. It belongs to the group of "virtual indirect" foreign investors: it is in majority foreign ownership but under Hungarian control. Videoton is the largest electronics manufacturing service provider 
Table 4. Selected indicators of the Hungarian companies, million EUR

\begin{tabular}{l|c|c|c|c|c|c|c|c|c}
\hline & \multicolumn{3}{|c|}{ Richter Gedeon } & \multicolumn{3}{c|}{ Videoton Holding } & \multicolumn{3}{c}{ Mediso } \\
\hline Year & 2015 & 2016 & 2017 & 2015 & 2016 & 2017 & 2015 & 2016 & 2017 \\
\hline $\begin{array}{l}\text { Operating } \\
\text { revenues }\end{array}$ & 1170 & 1259 & 1432 & 502 & 518 & 558 & 39 & 34 & 29 \\
\hline Total assets & 2393797 & 2628984 & 2451219 & 451 & 441 & 470 & 45 & 50 & 52 \\
\hline ROE (\%) & 9.68 & 10.01 & 2.09 & 14.51 & 13.39 & 12.97 & 19.84 & 11.71 & 3.34 \\
\hline
\end{tabular}

Source: Annual reports and balance sheets of the companies.

firm in the CEE region, headquartered in Székesfehérvár (a town located about 60 kilometres from Budapest, connected with the capital city by a highway). Mediso is a quickly growing and internationalising, at present already medium-sized firm, producing medical precision instruments.

\section{Richter Gedeon Plc.}

Richter Gedeon is a Hungarian pharmaceutical firm with a very long tradition; its predecessor was established back in 1901; and it survived the planned economy period as one of the most important pharma firms in the CMEA (Council for Mutual Economic Assistance) division of labour. It is a highly innovative company, being responsible for the highest share in Hungarian $R \& D$. Its main activities are research, development, manufacturing and marketing of pharmaceutical products. The firm maintained its important position and market share in Hungary (and the (former) CMEA countries) even in the post-socialist era, and has been one of the leading companies of the country. Richter Gedeon was privatised in a special way: its shares were introduced in the Budapest stock exchange in three tranches, resulting in a dispersed ownership structure. The company is majority foreign-owned, but there is no controlling owner. On the other hand, there is a relatively substantial state ownership in it (25.25\%). Because of the substantial (majority) foreign ownership in the firm, it can be categorised as an indirect foreign investor that is a non-indigenous company using the Hungarian subsidiary as a "mediator" for its foreign expansion in third countries. However, in the case of Richter Gedeon, foreign majority ownership does not go together with foreign control. The main reason for that is that there are no major foreign owners with more than $10 \%$ of the shares: the largest foreign owner, Aberdeen Asset Management Plc., a financial investor owns only $9.79 \%$ of the shares. Thus, the ownership structure of Richter Gedeon is highly dispersed, and the control is in the hands of the Hungarian management (Antalóczy - Sass 2018). 
Richter Gedeon defines itself as a "specialty pharma" firm: it concentrates on the dispensation of specialty pharma drugs. Specialty drugs are specialised, high cost products, which are part of therapies for complex diseases and should be administered in a special way: they require special handling, distribution and administration. This is a high growth area for pharmaceutical firms and may constitute a good way to remain competitive for those firms, which cannot rely on cost advantages in production vis-á-vis emerging pharma firms coming mainly from Asia or on large-scale economies and brand names as those belonging to big pharma in developed countries (Pharmavoice 2014). Richter Gedeon specialised in gynaecological pharmaceuticals and due to its new development: cariprazine, an antipsychotic drug under clinical trials and previous discoveries in this area, its other area of specialisation is psychotic drugs.

After the transition process started, the company had to adapt and change its internationalisation strategy at least three times (Antalóczy - Sass 2018). First, after 1989 when former CMEA markets became more risky with the collapse of regional trade, then their problems were reinforced during the 1998 Russian and Asian crisis, and the company targeted new foreign markets (especially, in the Americas and emerging Asia). However, the company tried to capitalise on the fact that the brand and products were well known in the former CMEA countries: it acquired, together with another Hungarian pharma company, Egis, the specialised foreign trade agency ${ }^{13}$ for pharma products, Medimpex with its foreign representative offices. From the latter, Richter Gedeon became parent to the non-CMEA offices and it established its own network of offices in the former CMEA countries afterwards. The second change in strategy occurred after around 2004-2007, when negative developments in the domestic market together with industry developments globally induced the firm to change directions in company strategy: foreign markets, as opposed to the domestic one, and thus exports and FDI became even more important. The third strategy change was induced after 2010, by new developments mainly due to the global financial crisis. The top management took the decision to become a specialty pharma company. That brought over changes in the main destinations of FDI: acquisitions of pharma and biotech firms in the developed European countries (Germany and Switzerland) were the most important elements in that (Antalóczy - Sass 2018).

These strategy changes had their consequences on the internationalisation of the firm as well. At present, the company has a very high export/sales ratio, $89 \%$, which never went below $60 \%$ in the last two and a half decades and since 2007, it is permanently above 80\% (Antalóczy - Sass 2018). In terms of FDI,

13 In the planned economy, foreign trade was conducted through sector-industry-wise specialised foreign trade agencies. 
Richter Gedeon has a wide geographic outreach: it is present mainly with representative offices and with three production units (excluding the Hungarian one) in the former CMEA countries (Poland, Romania and Russia). Furthermore, it is also present in the Western European countries in almost all the EU member states with trading affiliates and with two production units in Germany and Switzerland. Another important focus of foreign expansion is Asia, where there are two production units in the form of joint ventures in China and India as well as trade representatives. The fourth main focus of foreign expansion is the Americas, where the firm is present mainly through trading affiliates and trading joint ventures (Sass - Kovács 2013). Thus, the company is highly internationalised, it has 33 foreign affiliates in 24 countries, including the faraway and the Western European ones, its TNI (transnationality index) was 50\% in 2013 (Sass - Kovács 2015).

\section{Videoton}

The Székesfehérvár-based Videoton is a large Hungarian-owned electronic manufacturing services (EMS) provider, which now belongs to the largest regional players supplying European, the US and Japanese electronics and automotive companies. It supplies, among others, well-known multinational firms such as Robert Bosch, Continental, Delphi, Luk, Suzuki and Visteon in the automotive industry and ABB, Braun, Electrolux, Legrand, Panasonic, Philips, Siemens, Stadler, Schneider Electric in electronics mainly through the Hungarian subsidiaries of these multinational companies. Videoton is the fourth largest European EMS. Based on its own traditional technologies, competencies and close cooperation with its partners, the company manufactures parts, sub-assemblies and modules in electronics, plastics and machinery. Videoton provides a wide range of products for the automotive, consumer electronics, household appliances, IT, office equipment and telecommunication industries (Videoton 2015; Sass 2016).

The predecessor of Videoton was established back in 1938. It was nationalised after World War II and became a major state-owned company in the 1980s, employing 18,000 people (chiefly in military-related production). After the collapse of its regional markets, the bankrupt firm was acquired by three Hungarian individuals in the framework of privatisation in 1992 and they are still the main owners of the company. This is now the largest industrial company in the country, owned by Hungarians. The company group's own capital is 330 million EUR and currently employs almost 9,000 employees, out of which more than 700 work in foreign subsidiaries. Furthermore, its hired agency workers amount to another 
2000 employees. ${ }^{14}$ Its revenues amounted to more than EUR 550 million in 2017. The company has invested heavily in technical and technological developments, which resulted in a four-times growth in turnover in the last ten years, as well as a $50 \%$ growth in the number of employees. ${ }^{15}$ The company continues to invest in new production facilities and technology, financed mainly from the profit of the company group and resulting in substantial capacity extension in $2018 .{ }^{16} \mathrm{In}$ order to maintain competitiveness, they invest in various Industry 4.0-related technologies as well ${ }^{17}$, and there are $R \& D$ projects in the pipeline ${ }^{18}$. An interesting "philosophy", which may explain the survival and success of the company, was expressed by one of its co-CEOs: we never accept that "it used to be so" 19 a mentality quite different from the majority of the leaders of Hungarian firms.

With regard to its production operations, apart from producing electronics and automotive products, the company also produces related metal and plastic products, thus it has a large and diverse industry portfolio. It also provides various services to its customers, such as engineering, supply chain management, back-end technologies, logistics, etc. The company's headquarters are located in Székesfehérvár, furthermore it has 10 other locations in Hungary and one outside the country. It is a group of at least 50 companies of various sizes linked to each other through various direct and indirect equity holdings (Sass - Kovács 2013).

As for its foreign subsidiaries, Videoton acquired $98 \%$ of the shares of a Bulgarian firm in Stara Zagora in 1999. It established a joint venture with a Ukrainian company, Tochpribor, in 2009 in Mukachevo. Moreover, it owns a Bulgarian holding company located in the capital, Sofia. Wages in both countries were and still are substantially lower than in Hungary. As a response to pressure for increasing wages in Hungary, the company transferred its most labour-intensive activities to these foreign subsidiaries, explaining why it is considered as one of the few examples of efficiency-seeking outward investors in Hungary (Sass - Kovács 2013). A German subsidiary, Videoton Handelsgesellschaft mBh may serve as a representative office.

14 https://www.portfolio.hu/vallalatok/a-videoton-arbevetele-elerheti-a-188-milliard-forintot. 307219.html (in Hungarian)

$15 \mathrm{https} / / \mathrm{www}$.portfolio.hu/vallalatok/a-videoton-arbevetele-elerheti-a-188-milliard-forintot. 307219.html (in Hungarian)

$16 \mathrm{https} / / / \mathrm{bbj} . \mathrm{hu} /$ business/videoton-to-build-new-production-facility-in-szekesfehervar_142865

17 https://www.napi.hu/magyar_vallalatok/nyolcmilliardert-bovitett-a-videoton-csoport. 682240.html (in Hungarian)

18 https://bbj.hu/business/videoton-unit-leads-huf-350-mln-rd-project_89488

19 https://forbes.hu/uzlet/nem-fogadtuk-el-azt-a-mondatot-hogy-igy-szoktuk-a-videotonvezerek-egymas-mellett/ (in Hungarian) 
The company is the most valuable privately-owned company in Hungary and the largest electronics multinational in the CEE region. While its structure is in the form of a holding company, it is located in Hungary and there are no subsidiaries in foreign (tax-optimising) mediator-countries involved in its foreign expansion. Thus, it is a definite case of a Hungarian multinational with direct outward FDI.

\section{Mediso}

Mediso is a good representative of highly innovative and quickly internationalising Hungarian companies, from which we can find quite many, especially in highly technology intensive sectors and activities (for example biotechnology or IT, Kozma - Sass 2019).

The company was established in 1990. Its main activity is the production of medical precision instruments, and within that the development, production, sales and servicing imaging diagnostic systems in nuclear medicine technique. It is owned by two Hungarian individuals, who were previously employees of Gamma Müvek, an innovative company established in 1920 for producing optical and electro-technical equipment ${ }^{20}$, which was supplemented in the seventies by nuclear equipment. At the time of the establishment of Mediso, the CEO had already a seven-year experience with the products which were later produced. The own capital of the company was more than 700 thousand EUR in 2017; its sales amounted to more than 27 million EUR, with $73 \%$ coming from exports ${ }^{21}$. Among its main foreign buyers, we can find the International Atomic Energy Agency and the US Bioscan..$^{22}$ It employed close to 300 employees in 2017 . The company is highly internationalised: though its foreign assets were around 43 million USD in 2015 only, it had one of the highest transnationality indices among the Hungarianowned or controlled foreign investor firms (Sass - Kovács 2015). This means that the average of the share of foreign assets in total assets, the share of foreign employees in total employees and the share of exports in total sales is $80 \%$.

The company is highly innovative; it won the Hungarian Innovation Prize in 2010. More than $50 \%$ of Mediso employees are engaged with R\&D and $75 \%$ of Mediso employees hold higher academic degrees. ${ }^{23}$ It is cooperating with numer-

\footnotetext{
20 https://www.elektro-net.hu/cikk-archivum/482-latogatoban-mediso-kft-nel (in Hungarian)

21 Balance sheet of the company.

22 https://www.napi.hu/belfold/mediso_orvosi_berendezes_fejleszto_es_szerviz_kft.504994. html

23 http://www.mediso.com/about.php
} 
ous hospitals, clinics and institutes, for example, the National Physical Laboratory of the United Kingdom.

The firm has one countryside unit in Hungary (Debrecen) and two, 100\%owned foreign subsidiaries: one in Poland (Łódż, established in 1996) and one in Germany (Münster, established in 2005) ${ }^{24}$. These latter were established with the aim of providing product-related services, such as being in touch with customers and reacting quickly to customer inquiries. Furthermore, there is a large distribution network, which operates in four continents.

Mediso is again a direct foreign investor, as it is owned by two Hungarian individuals in 53.5 versus 43.5 ratio $^{25}$. It capitalizes on its highly innovative nature, which is translated into constant development of the product portfolio and production processes and previous special knowledge of the CEO.

\subsection{Discussion}

The Czech Republic and Hungary are among the leading foreign investor countries in the group of the former transition economies. However, balance of payments data do not present a real picture about their outward FDI, as they contain data on investments realised by both locally-owned or -controlled firms and local subsidiaries controlled by foreign multinational companies. Analyses based on company level data point to a high concentration of outward FDI in terms of the number of investing firms in both countries, and they identify the most important locally-owned or -controlled investors (Sass et al. 2012 for Hungary or Zemplinerova 2012 for Czechia). Having a closer look at these leading companies reveals that the leading foreign investors in the two analysed countries can be categorised as "virtual indirect" outward investor firms. This means that they are in majority foreign ownership, as we saw in the case of the Czech PPF Group or the Hungarian Richter Gedeon, but they operate under domestic control. In the case of PPF, a foreign holding, established in the Netherlands by the Czech owners, is the owner of the Czech firm, thus this represents roundtripping (in the case of the Czech company). In the case of Richter Gedeon, the company is majority foreign-owned, but its ownership structure is dispersed, and thus, there is no foreign controlling owner, it is under local control.

The reason for the existence of these special types of firms can be found in the privatisation technique applied in these countries during the transition process, due to which certain companies could stay in domestic hands and under domestic

24 http://www.mediso.com/contact.php

25 Supplement to the balance sheet of the company from https://e-beszamolo.im.gov.hu 
control. Both countries applied a mix of different privatisation methods, with a few dominant modes of getting state-owned properties into private hands. In Czechia, the most important was the voucher-based mass privatisation, affecting around half of the value of the medium and large-sized companies (Louzek 2018). In Hungary, the dominant method was direct sales to outsiders, including introducing the shares of the companies in question in the Budapest stock exchange and selling them to foreign and domestic investors in the case of a few companies (Sutela 1998). (However, in the majority of cases, direct sale meant acquisition for cash by a foreign multinational company. As we saw in the case of Richter Gedeon, companies with a strong management could "choose" their way of privatisation, sometimes with the aim of keeping the company under their control. Management in many companies was not strong enough to do that in the Czech Republic - or at that time Czechoslovakia (Williams - Balaz 1999).) Thus, one of the privatisation methods mattered in each country from the point of view of the "creation" of the leading outward investing firms.

However, the "construction" through which these firms have become the leading foreign investors, differs in the two countries. In Czechia, during voucher privatisation, shares of state-owned companies were distributed free of charge, and in the subsequent third wave of privatisation, in the absence of the necessary regulations, large private wealth arose in the hands of a few oligarchs (Williams - Balaz 1999). This wealth has then been transferred abroad as money (in a few cases as capital in the form of FDI) and then it has travelled back to Czechia as FDI from abroad. In many cases, it goes to third countries as FDI, as it is backed by our comparison of Czech outward FDI data with the partner countries mirror data according to the ultimate owners' nationality. As it is obvious, the Czech owners control these "foreign" firms: both the headquarters abroad, (through them the firms in Czechia) and FDI realised from the foreign headquarters in the third countries. In Hungary, certain companies were privatised through introducing their shares in tranches in the Budapest stock exchange. Both foreign and domestic financial investors could buy these. As a result, the leading foreign investor companies in Hungary are in majority, but dispersed foreign ownership, with no major owner with above $10 \%$ of the shares or votes (regulations also reinforce that as even a more than $10 \%$ share is not translated into the same magnitude of votes). The management, composed mainly of Hungarian people, makes all decisions of strategic importance for the company, thus it operates under the Hungarian control. In a previous article (Sass et al. 2012), we showed that this is also the case for OTP Bank, MOL and Richter Gedeon, the leading Hungariancontrolled foreign investor firms. In that respect, the emergence of the leading foreign investing firms is "path-dependent" in both countries. Furthermore, the time lag between introducing the shares of the leading Hungarian firms on the 
stock exchange and the third wave of privatisation in Czechia explains the time lag between the start of substantial outward FDI by locally-owned or -controlled firms.

Therefore, in both countries, certain privatisation techniques enabled the management/entrepreneurs/bankers in question to keep or get (formerly) state-owned firms in their hands, and thus, privatisation techniques are important from the point of view of "enabling" outward FDI in company cases when the local management is in control (ČEZ, Richter Gedeon), or when entrepreneurs could collect shares of formerly state-owned companies (PPF Group). Privatisation mattered for other companies as well. The management could obtain control when the company is large enough, as it is not divided into small units (Videoton), and when the management and prospective owners have a clear vision about the strategy of the company. In certain cases, even companies, established in the post-socialist era, have certain "roots" in the planned economy, and they are able to capitalise on previous knowledge and contact (LINET, Mediso among our analysed companies). However, the emergence of new foreign investing firms represents a new era: they are less and less rooted in the pre-1989 era, many of them are quickly internationalising firms in a market economy environment, and thus, resembling more and more multinational companies emerging in other, more developed parts of the world.

\section{CONCLUSIONS}

Our paper dealt with multinational companies, originating from two countries in the CEE region: Czechia and Hungary. First, we showed that balance of payments data might be misleading in terms of showing the existence and real extent of outward FDI by locally-owned or -controlled firms for various reasons. One important reason is that b.o.p. contains data on outward investments by resident companies, regardless of their (ultimate) ownership. Thus, the outward FDI data are a sum of foreign investments realised by locally-controlled or -owned companies and by locally operating companies, which are subsidiaries of the foreign multinationals. These latter are called indirect outward FDI, which is quite frequent in both countries, as we show through company cases, and can be attributed mainly to tax optimisation, but also to other (organisational, regulatory, finance access) reasons.

We showed that the mirror data based on the nationality of the ultimate beneficiary owner of FDI do show that there is a much higher level of outward FDI from Czechia than previously thought, and the case is the opposite for Hungary - even when taking into account the limits of our data. The problematic results 
based on the balance of payments data are, to some extent, explained by our company case studies. We showed that in both countries the leading foreign investor firms can be categorised as "virtual indirect" foreign investors. This means that while they are in majority foreign ownership, they are under domestic (i.e. Czech or Hungarian, respectively) control. On top of that, in the case of Czechia, they are even in Czech control in a foreign location, while in the case of Hungary they are under Hungarian control in Hungary.

Another important result is that in the case of the leading foreign investors, privatisation techniques mattered. In the Czech Republic, voucher privatisation, and in Hungary, the introduction of the shares of certain companies in the Budapest stock exchange are the most important techniques from our point of view. The legal background and enforcement also matter: the absence of regulations to avoid the concentration of a large part of shares in a few holdings in Czechia and the presence of regulations in Hungary to avoid hostile takeovers in the case of the analysed companies helped the process.

Further research can be based on a more complete database, when other countries, including those which are among the important hosts to outward FDI from the two analysed countries, present their data according to the ultimate beneficiary owner principle. The number of analysed countries could also be extended, especially to other countries in the region at a similar level of development, such as Poland and Slovakia. Similarly, the analysis of the two countries could be extended by including a higher number of firms, which may underline certain specificities not present in the case of the six firms examined in this article. Furthermore, research could address other factors influencing the behaviour of local multinationals, for example the role of the tax rates and tax regulations in inducing local multinationals to transfer their headquarters abroad. Another possible topic may be the comparison of the performance of the firms, presented here, after their internationalisation and to make a link between their ownership structure and/or privatisation method and performance.

\section{REFERENCES}

Andreff, W. (2015): Outward Foreign Direct Investment from BRIC Countries: Comparing Strategies of Brazilian, Russian, Indian and Chinese Multinational Companies. The European Journal of Comparative Economics, 12(2): 79-131.

Andreff, W. - Andreff, M. (2017): Multinational Companies from Transition Economies and Their Outward Foreign Direct Investment. Russian Journal of Economics, 3: 445-474.

Antalóczy, K. - Sass, M. (2018): The Internationalisation of Richter Gedeon, the Hungarian Pharmaceutical Company, and Entrepreneurship in Hungary. In: Tõnis, M. - Arnis, S. - Purg, D. 
(eds): Entrepreneurship in Central and Eastern Europe: Development through Internationalization. London: Routledge, pp. 159-176.

Avast (2018): Avast Story at a Glance. https://investors.avast.com/our-story/at-a-glance/

Bellak, C. (1998): The Measurement of Foreign Direct Investment: A Critical Review. The International Trade Journal, 12(2): 227-257.

Bojnec, S. - Fertö, I. (2018): Globalization and Outward Foreign Direct Investment. Emerging Markets Finance and Trade, 54(1): 88-99.

Boudier-Bensebaa, F. (2008): FDI-Assisted Development in the Light of the Investment Development Path Paradigm: Evidence from Central and Eastern European Countries. Transnational Corporations, 17(1): 37-67.

ČEZ (2018): Skupina ČEZ - Výroční zpráva 2017. https://www.cez.cz/edee/content/file/investori/ vz-2017/vz-2017-cz.pdf

ČNB (2017): Balance of Payments Statistics. https://www.cnb.cz/miranda2/export/sites/www.cnb. $\mathrm{cz} / \mathrm{cs} /$ statistika/platebni bilance stat/publikace pb/pzi/PZI 2016 CZ.pdf

ČT24 (2018): Firmě ČEZ klesl v pololetí zisk I tržby. https://ct24.ceskatelevize.cz/ ekonomika/2559166-firme-cez-klesl-v-pololeti-zisk-i-trzby-chybely-ji-mimoradne-prijmy-aprecenovala

Deloitte (2018): Technology Fast 50 Central Europe. https://www2.deloitte.com/content/dam/ Deloitte/ce/Documents/about-deloitte/ce-technology-fast-50-2018-report.pdf

EnergyHub (2018): Balkánská dobrodružství ČEZ. https://cz.energyhub.eu/clanek/pod-lupou 159075-balkanska-dobrodruzstvi-cez

Ekonom (2011): Linet založil mezinárodní holding v Nizozemsku. https://ekonom.ihned.cz/c152849890-ekonom-cz-linet-zalozil-mezinarodni-holding-v-nizozemsku

Forbes (2018): 80 nejbohatších Čechů 2018. https://miliardari.forbes.cz/

Ford, T. C. - Rork, J. C. - Elmslie, B. (2008): Considering the Source: Does the Country of Origin of FDI Matter to Economic Growth? Journal of Regional Science, 48(2): 329-357.

Gorynia, M. - Nowak, J. - Trąpczyński, P. - Wolniak, R. (2015): Outward FDI of Polish Firms: The Role of Motives, Entry Modes and Location Factors. Journal of East European Management Studies, 328-359.

Ihned (2018a): PPF převezme firmy norského Telenoru. https://byznys.ihned.cz/c1-66205350ppf-prevezme-firmy-norskeho-telenoru-nakup-schvalila-evropska-komise-za-operatory-vmadarsku-ci-bulharsku-zaplati-pres-70-miliard-korun

Ihned (2018b): Kellnerova PPF dokončila akvizici biotechnologické Cytune Pharma. https:// byznys.ihned.cz/c1-66229870-kellnerova-ppf-dokoncila-akvizici-biotechnologicke-cytunepharma-od-pristiho-roku-bude-testovat-lek-proti-rakovine-na-lidech

Ihned (2018c): Američané a Č́ńnané bojují o Linet. https://archiv.ihned.cz/c1-66336790-americanea-cinane-bojuji-o-linet

Ihned (2019): Českých firem v daňových rájích je nejméně za posledních pět let. https://byznys. ihned.cz/c1-66422600-ceskych-firem-v-danovych-rajich-je-nejmene-za-poslednich-pet-letmomentalne-jich-tam-ma-vlastnika-necelych-13-tisic-spolecnosti

IMF (2009): Balance of Payments and International Investment Position Manual. (Sixth ed.). International Monetary Fund, Washington, D.C.

Jaklič, A. - Svetličič, M. (2009): Survey Ranking Slovenian Multinationals Finds Them Small and Vulnerable, but Flexible and Increasingly International. http://ccsi.columbia.edu/files/2013/11/ Slovenia_2009.pdf

Jindra, B. - Hassan, S.S. - Günther, J. - Cantner, U. (2015): European Integration and Outward FDI from Central and Eastern Europe - Is There Any Evidence of Knowledge-Seeking? JCMS: Journal of Common Market Studies, 53(6): 1248-267. 
Kaliszuk, E. - Wancio, A. (2013): Polish Multinationals: Expanding and Seeking Innovation Abroad. http://ccsi.columbia.edu/files/2013/10/Poland_2013.pdf

Kalotay, K. (2012): Indirect FDI. The Journal of World Investment \& Trade, 13(4): 542-555.

Kalotay, K. - Sass, M. (2019): Managing in Emerging Markets in Central and Eastern Europe. In: Robert, G. - Meyer, K. E. (eds): The Oxford Handbook of Management in Emerging Markets. New York, Oxford: Oxford University Press, pp. 763-795.

Kosztowniak, A. (2016): Verification of the Relationship between FDI and GDP in Poland. Acta Oeconomica, 66(2): 307-332.

Kozma, M. - Sass, M. (2019): Hungarian International New Ventures - Market Selection and the Role of Networks in Early Internationalisation. Society and Economy, 41(1): 27-45.

Louzek, M. (2018): Czech Privatisation 25 Years Later. The World Economy, 41(3): 975-986.

Lupa (2019): Huawei chce postavit tuzemské 5G sítě s PPF. https://www.lupa.cz/clanky/huaweichce-postavit-tuzemske-5g-site-s-ppf-uz-podepsala-prvni-dokument/

OECD (2015): Measuring International Investment by Multinational Enterprises. Implementation of the OECD's Benchmark Definition of Foreign Direct Investment. (4th ed.) OECD, Paris.

Pharmavoice (2014): Specialty Pharma on the Rise. Pharmavoice, nov/dec. https://www.sas.com/ content/dam/SAS/en_us/doc/other2/pharmavoice-specialty-pharma.pdf

PPF (2018): Výroční zpráva skupiny PPF 2017. https://www.ppf.eu/files/ppfgroup-annualacounts2018-public.pdf

Radlo, M. J. - Sass, M. (2012): Outward Foreign Direct Investments and Emerging Multinational Companies from Central and Eastern Europe: The Case of Visegrád Countries. Eastern European Economics, 50(2): 5-21.

Rugraff, E. (2010): Strengths and Weaknesses of the Outward FDI Paths of the Central European Countries. Post-Communist Economies, 22(1): 1-17.

Sass, M. (2016): Emerging CEE Multinationals in the Electronics Industry. In: Trąpczyński, P. - Puślecki, Ł. - Jarosinski, M. (eds): Competitiveness of CEE Economies and Business: Multidisciplinary Perspectives on Challenges and Opportunities. Cham: Springer International Publishing, pp. 149-173.

Sass, M. - Antalóczy, K. - Éltető, A. (2012): Emerging Multinationals and the Role of Virtual Indirect Investors: The Case of Hungary. Eastern European Economics, 50(2): 41-58.

Sass, M. - Kovács, O. (2013): A Snapshot of the Leading Hungarian Multinationals 2011. ICEG European Center and Vale Columbia Center. http://ccsi.columbia.edu/files/2013/10/Hungary_2013. pdf

Sass, M. - Kovács, O. (2015): Hungarian Multinationals in 2013 - A Slow Recovery after the Crisis? Columbia Center on Sustainable Investment, a Joint Center of Columbia Law School and the Earth Institute, Columbia University, New York, 5 March 2015.

Stocker, M. (2019): Survival, Growth, and Performance of Hungarian International New Ventures. Society and Economy, 41(1): 47-64.

Stoian, C. (2013): Extending Dunning's Investment Development Path: The Role of Home Country Institutional Determinants in Explaining Outward Foreign Direct Investment. International Business Review, 22(3): 615-637.

Sutela, P. (1998): Privatization in the Countries of Eastern and Central Europe and of the Former Soviet Union. Working Paper, No. 146, February, UNU Wider, Helsinki.

Svetličič, M. (2004): Transition Economies' Multinationals - Are They Different from Third World Multinationals? Proceedings of the 8th International Conference on Global Business and Economic Development (ed.: Chakraborty, C.). Montclair: Montclair State University.

UNCTAD (1998): World Investment Report. Trends and Determinants. Geneva and New York. 
Videoton (2015): One Company - Infinite Possibilities. http://www.videoton.hu/downloads/ videoton_general_eng.pdf

Vlčková, J. (2019): SMEs in Medical Technology Global Production Networks: The Case of Czechia. Society and Economy, 41(1): 65-86.

Wang, Ch. - Clegg, J. - Kafouros, M. (2009): Country-of-Origin Effects of Foreign Direct Investment. Management International Review, 49(2): 179-198

Williams, A. M. - Balaz, V. (1999): Privatisation in Central Europe: Different Legacies, Methods, and Outcomes. Environment and Planning C: Government and Policy, 17: 731-751.

Zemplinerova, A. (2012): Czech OFDI Investment Strategies and Motivation to Invest Abroad. Eastern European Economics, 50(2): 22-40.

Open Access. This is an open-access article distributed under the terms of the Creative Commons Attribution 4.0 International License (https:/creativecommons.org/licenses/ by/4.0), which permits unrestricted use, distribution, and reproduction in any medium, provided the original author and source are credited, a link to the CC License is provided, and changes - if any - are indicated. (SID_1) 